\title{
Driving learning development professionalism forward from within
}

\section{lan Johnson}

University of Portsmouth, UK

\section{Abstract}

Current conceptions view professions as negotiable, transient territories which are shaped by the discourses that describe them. The voices which influence how a profession evolves arise from both within and outside it. Theories on professionalism have been rigorously applied to teaching and academia. Learning Development exists within both spheres, yet its complex growth patterns have resulted in a fragmented and less theorised sense of professional identity. The rationales which create and fund Learning Development roles lean towards a model of fixing 'deficits' in students and their work; meanwhile, Learning Development's professional association, ALDinHE, rejects those same deficit premises. In this article, using a theoretical framework and terminology from Evans $(2008 ; 2011)$, I analyse the differences between those states of professionalism 'demanded of' and 'enacted by' Learning Developers. By coding various external and internal documents which frame job roles, I deduce how the two 'professionalisms' interact to resolve their inherent tensions; I identify a point of coalescence around Learning Development as a niche for mediation and demystification. I also explore how Learning Developers believe their profession can best evolve and sustain, via community-internal voices in literature and a survey of 14 ALDinHE members. Findings suggest that Learning Development remains a unique and valued activity, to which professional identity is attached. However, a precise sense among the ALDinHE community of what 'equals' a professional Learning Developer remains debated. More coherent is the community's wish to see its values (Learning Development) permeate across the wider higher education landscape.

Keywords: Learning development; professionalism; identity; perceptions; working practices; academic literacies. 


\section{Introduction}

This article investigates the current and potential future professionalism of Learning Development in UK higher education (HE). I am employed as a Learning Developer and am a member of the Association for Learning Developers in Higher Education (ALDinHE); thus, I write from and give value to a community-insider perspective, as well as investigating the views of other interested groups. Such exploration adds to debates about evolving the field amid a climate of rapid change (Webster, 2015; Buckley and Briggs, 2017). In addition, it brings into focus the core values of ALDinHE (ALDinHE, 2018a). I argue that those values should remain as visible as possible to students navigating the constant flux within the HE landscape. Historically, Millerson (1964) and Freidson (1999) have theorised that professions' statuses should be benchmarked against a set of universal traits. However, such models are argued to have been superseded (Evetts, 2014) when considered in light of the rapid and ongoing changes to higher education. As Collini (2017) sets out, today's HE climate is characterised by marketisation, massification and measurement of the student experience, such as through the Teaching Excellence Framework (TEF). Given that type of landscape, Evetts advocates that professions should now be framed not through traits but as shifting, contested territories shaped by the discourses that describe them. Such discourses are influenced by outside groups (McClelland, 1990; Evetts, 2014) such as managers, academics and students. Yet as insiders with powerful collective values, Learning Developers can also exert influence. This article asks: 'how can we best do that?'

With discourse negotiation firmly in mind, I use Evans' (2008) model of 'reified states of professionalism', originally applied to schoolteachers (Evans, 2011), as a theoretical framework through which to analyse Learning Development. Evans (2008, p.8) recognises both 'demanded' and 'enacted' states of professionalism which inform each other. The demanded professionalism is filtered through individual and collective values to reach its enacted form, which in turn impacts the future demands. To contextualise, Learning Developers are agents over aspects of their current and future practice despite the presence of external expectations; this picture resonates with recent portrayals of Learning Development as operating within a contested space (Hilsdon, 2017, 2018). In this paper, I use 'Learning Development' in a wide sense to encompass work directly involving the core values of ALDinHE (2018a). Five such values emerged from the 
ALDinHE 2017 conference community keynote, namely: 'working alongside students to make sense of and get the most out of higher education; making HE inclusive through emancipatory practice, partnership working and collaboration; adopting and sharing effective LD practice within the HE community; commitment to scholarly approach and research related to LD; and critical self-reflection, on-going learning and a commitment to professional development' (ALDinHE, 2018b). The process of arriving at the values means that they can be taken to represent a convergence of the community's opinion. That said, I am mindful that 'Learning Development' blankets many more roles than the narrower job title 'Learning Developer' and that this diversity reduces the likelihood of opinions completely agreeing. However, a premise for this article is that, to some extent, an internal consensus exists concerning the core values: that they are entailed by 'Learning Development' and embodied by its practitioners.

\section{Aims and rationale}

This article investigates Learning Development's niche within the professional landscape of academia. I use secondary and small-scale primary research to tackle two key questions:

1. How do external and internal viewpoints on the professional status of Learning Development compare?

2. Assuming Learning Developers want strong professional recognition, then for what do we want to be recognised?

Firstly, I summarise ideas from the literature based on professionalism, HE and Learning Development. Next, for the first question, I compare internal and external perceptions of Learning Development job roles via document coding and analysis. For the second question, I have an exploratory goal of stimulating further debate and discussion more than reaching definitive answers. I gathered views from a survey of Learning Developers at the 2018 ALDinHE conference. In asking 'professionally recognised for what?', key questions surround whether Learning Development might most beneficially be established as its own discipline (Samuels, 2013), or within the 'third space' between academics and 
professional services staff (Whitchurch, 2008, p.3), or among a broader professional group of higher educators (MacFarlane, 2011).

The route taken has profound implications for how future students will perceive the essence of Learning Development. Student perceptions are affected by multitudinous factors, some controlled institutionally and some individually. The former include the ways in which universities name, locate and discuss our role (Murray and Glass, 2011). These variables affect students' decisions about whether, why and how to access services. Variables in the latter category, such as the pedagogic approaches adopted, represent 'enacted' professionalism (Evans, 2008). These factors will shape students' perceptions of the gains available via our services.

Aligning student perceptions with our own would involve fostering the understanding that Learning Developers embody 'Academic Literacies' principles (Lea and Street, 1998) as captured in the ALDinHE core values (ALDinHE, 2018b). Specifically, we wish to dispel student notions of themselves or their work as deficit-based - as a problem to be fixed. That represents a challenging task within a neo-liberal educational climate which can jar against those values (Hilsdon, 2018). However, it is vital that we continue to strive. Where students perceive gains, feel satisfied and give feedback which reflects that, the opportunity for Learning Development to sustain and evolve is enhanced (Murray and Glass, 2011; Verity and Trowler, 2011). This article spotlights some key debates around the best use of our strategic influence towards that outcome.

\section{Literature review}

\section{Changing trends in professionalism}

To assess the professional status of Learning Developers, I start by considering the evolution of the term 'professionalism'. Attempts to model professions gained traction in the 1960s; shaped within sociological thought, the models sought to identify several professional traits (Robson, 2006; Evetts, 2014). Millerson (1964) identified six: a knowledge base; established training and education routes; a sense of responsibility; an ethical code; altruistic spirit; and high autonomy. As the models were applied to teaching, the traits were subsumed into three categories: 'knowledge', 'service/responsibility' and 'autonomy' (Hoyle and John, 1995; Robson, 2006; Sexton, 2007). 
Trait-based theorists averred that when an occupation could demonstrate these characteristics, it gained 'professionality' (Evans, 2008). In turn, involved professionals could create specialised niches, from within which they could control the occupation. Opinions are split as to whether internal control is desirable. Freidson (1999) argues that it creates altruistic behaviour, while a more cynical standpoint holds that it can instead encourage self-serving action designed to preserve elite status (Johnson, 1972; Larson, 1977).

Today, the more pertinent question concerns not whether internal control is desirable, but even possible. In older models, the trait 'autonomy' implied internal control. However, Robson (2006) views autonomy as subservient to the neo-liberal buzzword of 'accountability' in UK-based HE. Elsewhere, accountability-based professionalism is named as 'managerial' (Apple, 2000; Whitty, 2006), 'performative' (Ball, 2000; Wilkins, 2011), 'incorporated' (Hatcher, 1994; Day et al, 2006) or 'governmental' (Beck, 2008). Such framings, for Neal and Morgan (2000) and Williams (2008), result from the word 'professional' now being applied to everyone, rather than demarcating a specialism. As such, trait-based models are arguably unfit for present purposes. Taking this line, Evetts (2014, p.40) states that professions are now framed by the language that commonly describes them: the professionalism 'discourse'. A discourse view sees professions as territories that are disputed, negotiated and shifted longitudinally (Ozga and Lawn, 1981).

\section{Evans' (2008 and 2011) model as a theoretical framework}

A form of professionalism shaped by policy discourse from above was evident in Evans' (2011) study on schoolteachers. Evans (2011) identified three 'dimensions of professional being', termed 'behavioural', 'attitudinal' and 'intellectual' (p.855). To the dimensions, she mapped each of the government's 41 'Professional Teacher Standards' (Training and Development Agency, 2007). Her picture showed a heavy weighting towards behaviours, leading to a description of 'lop-sided' professionalism (p.861). Therein, concerns with adhering to methods outweigh those regarding underpinning values or theory. However, for Evans, this outsider viewpoint is not the full picture. Evans utilised her 2008 model to argue that the professionalism demanded of teachers would undergo significant character change before being enacted. Evans (2011) added two further professionalisms: 'as prescribed', to reflect the perceptions of analysts such as academics; and 'as 
deduced', to account for how the profession portrays itself externally. For Evans, the key components of professionalism are inter-related, as I have summarised graphically in Figure 1.

Figure 1. Visual representation of reified states of professionalism, adapted from ideas in Evans (2008).

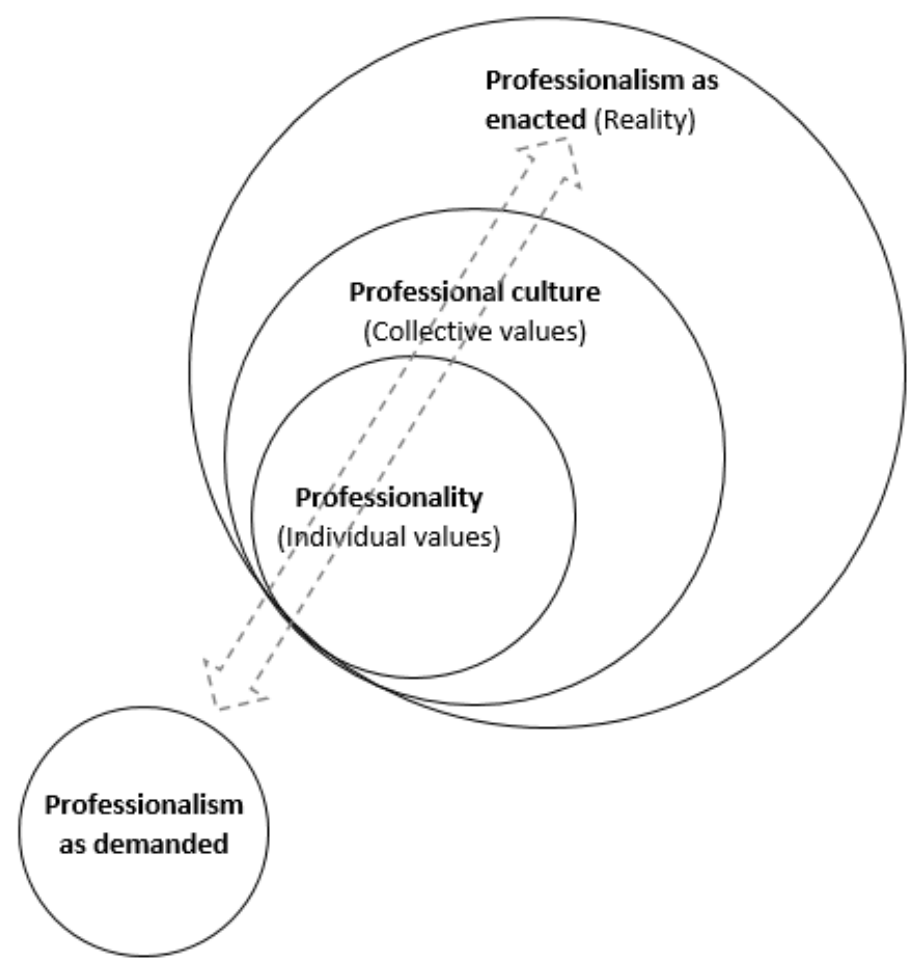

Viewed through this multi-layered model, teachers' professionalism-as-demanded is filtered through individual values ('professionality') and collective values ('professional culture') to reach the enacted version (Evans, 2011). The relationship can also act bidirectionally to influence future demands. Wilkins (2011) offered a real-life view of the process in finding that newly-qualified schoolteachers could reconcile the inevitability of big-picture accountability with feelings of autonomy behind the classroom door. Evans' (2011) model has resonance for my study; in Learning Development terms, it aligns with Hilsdon's (2017) portrayal of a negotiated field where institutional, collective and individual agency interact to produce professional practice. That space is perhaps best explored after first moving outwards to the broader professional landscape of academia. 


\section{Professionalism and academia}

Perkin (1969, p.227) identified academia as 'the key profession'. His trait-based model situated academics at the forefront of disciplinary fields, as controllers of the knowledge generated by research and disseminated to future professionals through teaching. In a replication 45 years later, Shattock (2014) showed powerfully how each professional trait used by Perkin had been eroded. Examples include reductions to: the extent and content of research within contracts; the authority of professional bodies; job security; the societal value of knowledge produced inside academia versus outside; and influence on educational policy (Shattock, 2014). One explanation is the increased policymaking focus on education as an economic more than social enterprise (Collini, 2017). On this note, Stronach et al (2002, p.109) discussed academics as being caught between 'ecologies of practice' and 'economies of performance', mirroring the wider shift towards conceiving professions as shaped by discourses rather than traits.

Academics, then, face professional identity uncertainties. In relation, a body of literature (Barnett, 2003; Clarke, Hyde and Drennan, 2013; Harris, 2005; Kogan, 2000; Lewis, 2014; Nixon, 2008; Williams, 2008) broadly coalesces on two points. The first is that academics can no longer identify as professionals through their access to disciplinary knowledge alone, yet would also resist teaching credentials being central to their professional identity. The second is that academic professionalism is, therefore, best re-imagined as an altruistic endeavour towards students and society. Using that conception, Williams (2008) argues that agendas founded both on service and morals can be satisfied simultaneously. Academic professionalism is often described as fragmented. MacFarlane (2011, p.59) explores how generalist academic roles have been 'unbundled' into specific individual focuses such as tuition, management or quality control. MacFarlane describes as 'paraacademics', those whose roles straddle a previously clear-cut divide between academics and administrators, elsewhere termed 'the Third Space' (Whitchurch, 2008, p.3). In a position consistent in subsequent literature (Kolsaker, 2014; Lewis, 2014; Veles and Carter, 2016), Whitchurch emphasises that Third Space roles are filled both by academics and former administrators. She believes that by traversing the borders of the third space, both groups can aid career progression and institutional goals. Kolsaker's (2014) interviews at a mid-sized UK university only partly support Whitchurch's point, in 
highlighting the growing autonomy and satisfaction felt by professional services staff, but a converse notion of de-professionalisation among academics.

An interesting argument from Kolsaker (2014) is that while academia's roles are fragmenting, their intended outcomes are converging. The point of unison is perhaps the need to satisfy both service-based and moral-based agendas. The two conceptions may appear initially paradoxical; the first pre-supposes education as serving economic ends, and the second as serving social ends. Application of Evans' (2008) model (see Figure 1) helps to resolve the paradox. It could be argued that in the filtration process between the demanded and enacted professionalisms, the economic view gradually meets and coexists with the social view.

\section{Professionalism and learning development}

Where does this leave Learning Development within today's uncertain HE landscape? Hilsdon (2011) compiled a history of Learning Development's emergence and evolution, of which a few points seem most salient. Foundations lie in intellectual traditions concerning how students learn (Marton, Hounsell and Entwistle, 1984) and how pedagogy responds (Gibbs, 1977). However, job roles created since the 1990s and often termed 'Learning Support' have been rationalised and funded by different agendas, namely widening participation (Hilsdon, 2011) and student retention and experience (Hill and Tinker, 2013). Murray and Glass (2011) found substantial inconsistencies in how universities locate, name and discuss learning development practice, with profound implications for professional status. However, from early accounts of such roles (Wolfendale and Corbett, 1996) to more recent ones (Hilsdon, 2017), external perceptions of students as having deficits to be remedied have been steadfast.

In explaining the growth of the Learning Development in Higher Education Network (LDHEN), Hilsdon (2011) elucidates that involved professionals gradually united under the values of Learning Development. Somewhat ironically, those values reject the deficitbased premises responsible for job creation. Instead, Learning Development draws upon the academic literacies model (Lea and Street, 1998) to problematise: 
...the complex codes and conventions that students must negotiate to become accomplished players in the academy ... the ways in which issues of meaningmaking and identity are implicated, not just in student writing, but in teaching and learning more generally. (Ivanic and Lea, 2006, p.112).

Intrinsic to the above quote is an understanding that academia speaks its own language, which, for Lillis (2001), is likely to alienate students. Hilsdon (2017) argues that bridging the gaps that cause such alienation is the chief responsibility assumed by Learning Developers. The result is a professional status which chimes internally with notions of mediation and demystification. In that conception, I imagine a slightly different 'third space' as a bridge between students' worlds inside and outside the university.

My earlier claim, theoretically grounded in Evans' (2008) model, was that service-based external conceptions of education will intersect with internal morally-based conceptions, and reconcile in the enacted professionalism. The evolution of 'Learning Support' into 'Learning Development' is a microcosm of that process. Yet interestingly, Hilsdon's (2017) analysis of Learning Developers' viewpoints reveals feelings that the reconciliation requires us to use 'stealth' and 'subversion' by working among, but sometimes quietly against, more hegemonic voices. This raises a question concerning the longer-term viability of such strategic acts within an increasingly marketised HE sector. Perhaps a more coherent professional identity will be required to ensure sustainability.

The possible nature of a joined-up identity motivated my second research question. For what, I wondered, would Learning Developers like professional recognition? As a starting point, Samuels (2013) argued that a more cohesive status required Learning Development to seek recognition less as a 'movement' (p.4) and more as a subject discipline. In defining 'discipline', Samuels cited Becher (1989), who characterised disciplines as socially organised 'tribes' occupying epistemologically organised 'territories'. On both notes, Samuels believed that Learning Development should prioritise forging links to institutional discourses and research on how students learn and outlined a blueprint towards doing so.

Many of Samuels' (2013) recommendations were continuations, for example maintaining associations with widening participation and retention agendas and cultivating a status as intermediaries with human interest in students. Samuels also made two suggestions 
requiring greater progress: that Learning Development should establish an epistemologically-coherent research voice and tailored certification routes. The actions were benchmarked against those of the Staff and Educational Development Association (SEDA), whose primary focus is to: "promote innovation and good practice in higher education [among staff]" (SEDA, n.d.). Samuels (2013) praised the greater progress made by SEDA, while attributing that largely to its establishment 14 years prior to ALDinHE. However, one outcome of using Educational Development as a model could be an eventual coalescence of the two groups, the merits of which divides opinions (Gibbs, 2009).

I became interested in establishing how Learning Developers would now view Samuels' blueprint with the benefit of five years' hindsight. Several of Samuels' suggestions have doubtless seen progress. Notably, in 2018 ALDinHE launched an independent Certified Practitioner (CeP) recognition scheme at two levels (Briggs, 2018; Briggs, Carter, Koulle and Rafferty, 2018) as well as identifying LD-related research among its five values.

Crucially, however, Samuels' (2013) paper is premised on disciplinary establishment being the preference. That stance could now be questioned, especially given the erosion of disciplinary belonging as a barometer for professional identity (Williams, 2008).

Conversely, the Third Space model attaches importance to disciplinary boundaries being beneficially crossed, not used to delimit responsibilities (Whitchurch, 2008). Discovering Learning Developers' viewpoints is, therefore, a key objective of my second research question.

\section{Methods}

To apply the different 'professionalisms' imagined by Evans $(2008,2011)$ to Learning Development, and compare them, I selected three documents which frame its activity from different standpoints. Firstly, for 'demanded' professionalism, I used a convenience sample of the role and person descriptors of a Learning Development job advertisement. The advert was produced in a post-1992 institution, whose primary model for Learning Development, including the job advertised, is departmentally-based. That model is neither uncommon nor most typical among the many found in the UK (Murray and Glass, 2011). I recognise, however, that the job description is likely to bear the hallmarks of the specific 
role and university concerned, marking an acknowledged limitation to my research. Findings may be indicative of the wider situation but there would doubtless be benefit in further research which samples a cross-section of institutions' job descriptions to gain a fuller picture. The second document was the UK Professional Standards Framework (UKPSF) (Higher Education Academy, 2011). As an independent gatekeeping document for teaching fellowships, the UKPSF represents an analytical 'prescribed' framing of professionalism (Evans, 2011). Thirdly, I selected ALDinHE's (2015) 'LD-MAPS', in effect a community role specification of Learning Development activities, for a viewpoint on the 'deduced' professionalism (Evans, 2011) presented to the wider world.

I adopted the coding procedures that Evans (2011) used to illustrate teachers' professionalism. As mentioned, Evans established three dimensions of professional being: behavioural, attitudinal and intellectual. She explained how the teacher standards were mapped to these, using the example: "recognise and respect the contribution that ... [various parties make to children's development...]" (p.860). The two command verbs, recognise and respect, meant this standard was double-categorised: respect to the 'attitudinal' dimension, and recognise to the 'intellectual'. Evans noted that recognise may also map to a 'behaviour', but in unpicking the standard she perceived a request for a more intellectual recognition. Evans preferred to single-classify each command verb, although observing that it was not always possible. On that note, another documented example is "Communicate effectively with children ..." (p.860), mapped as a behaviour despite recognition that attitudes are also inherent. Evans (2011) recognised that often the behaviour was made more transparent in performance standards than the underpinning attitude or intellect, with a likely corresponding skew in results.

I replicated these coding procedures to classify each descriptor in my three selected documents (see Appendix 1 for a sample). Coding was sometimes complex, for example in: "Identify gaps in resource availability and, under guidance, research, develop and evaluate high-quality resources" (university role descriptor 9). Four processes were requested, necessitating at least four categorisations. Identify, evaluate and develop, as tangible actions, each mapped to the 'behavioural' dimension. Meanwhile, I double-coded research as 'intellectual' and 'behavioural', as the descriptor implies both intellectual engagement and material action. This example has been deliberately included to demonstrate how I treated complex instances, although many descriptors could be more 
straightforwardly single-mapped. In both Evans' (2011) processes and my replication, subjectivity was mitigated by making direct lexical links between the command verbs, the context within which they were used, and the three dimensions. It is acknowledged that subjectivity would have been further reduced, had I elected to use a second coder and check inter-rater reliability; however, this was not possible within the timescale of the project.

To investigate the internal perspective on the professionalism of Learning Development, I devised eight multiple choice questions. These formed a real-time polling activity, using PollEverywhere, with a convenience sample (Denscombe, 2010) of 14 attendees at my professionalism workshop at the 2018 ALDinHE conference (Johnson, 2018). Delegates were informed that the ideas generated may, anonymously, contribute to a written paper reporting on the session, and given the option to opt-out verbally, which no participant took up. All those polled were ALDinHE members, therefore identified with 'Learning Development' although not necessarily as 'Learning Developers'. All responses were anonymised instantly and appeared aggregated on-screen. The results were discussed in breakout groups then collectively. I made notes about key emergent themes. Due to the small sample size, the results represent a snapshot of the wider range which will exist within the ALDinHE community.

\section{Results and discussion}

\section{How do internal and external perspectives on the professional status of Learning Development compare?}

Figure 2 shows the results of the coding activity. From these different pictures of the professionalisms of Learning Development, various observations are prudent. The UKPSF, representing prescribed professionalism, is fairly evenly spread in attaching $42 \%$ of its criteria to intellect, $21 \%$ to attitudes and $37 \%$ to behaviours. By comparison, the demanded professionalism in the job advertisement mirrors Evans' (2011) lop-sided picture for schoolteachers, in elevating behaviours to $72 \%$, almost double their role in the UKPSF, and reducing attitudes to $6 \%$. A possible explanation is that a 'performative' professionalism (Ball, 2000) has been uncovered in the job specification. Such framings are concerned chiefly with accountability, which is made most explicit through expected behaviours (Ball, 2000). Evans' (2011) point - that the behavioural dimension tends to 
permeate more readily into descriptors than the subtler underpinning values and knowledge - adds caution to the explanation.

Figure 2. Learning Development as variously professionalised.

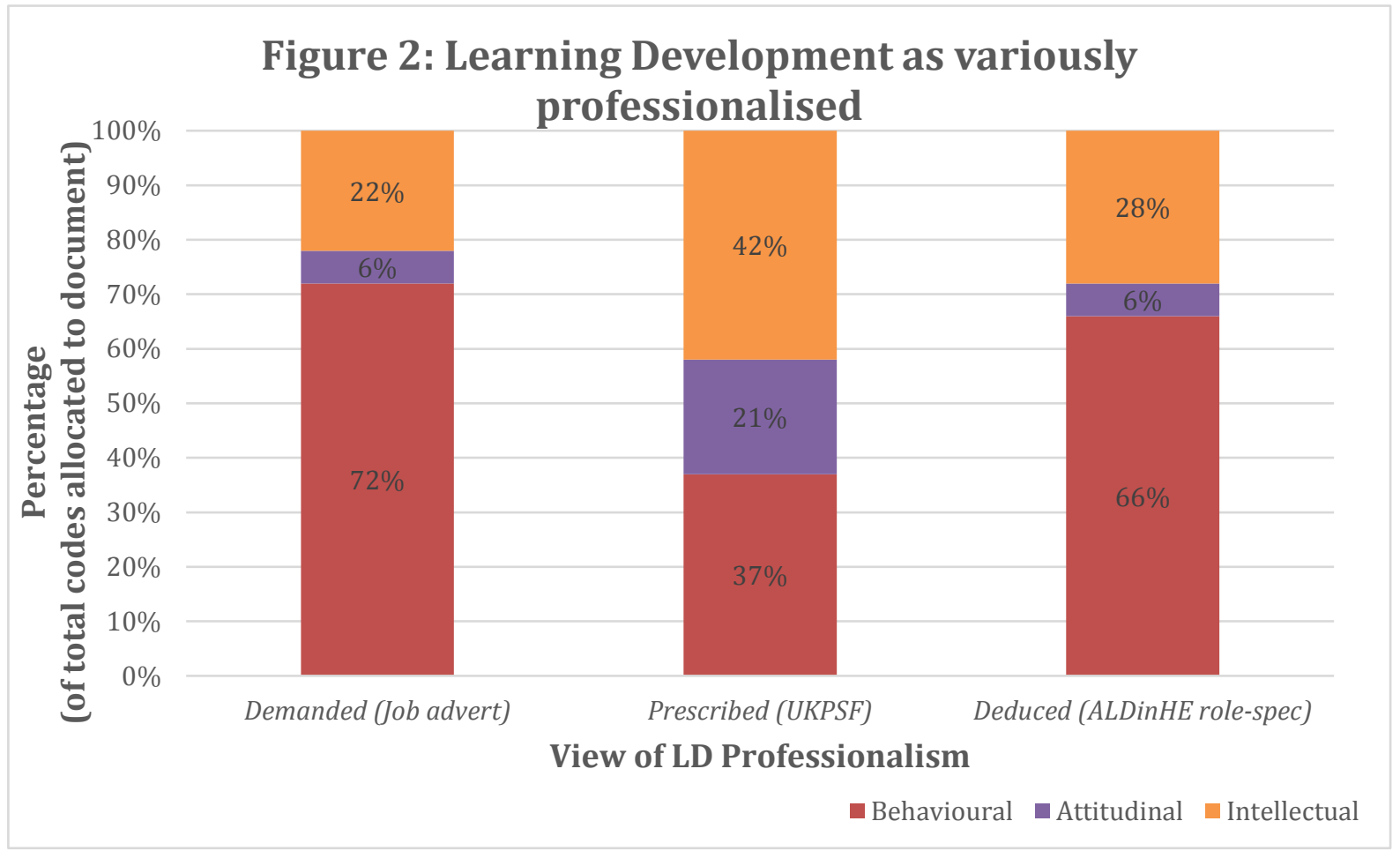

Equally of interest, the ALDinHE community role descriptors, representing deduced professionalism, align closely with the role specification. There is one minor difference: in the ALDinHE document, a $6 \%$ swing is present from behaviours to intellect, hinting at the Learning Development community's wish for a higher level of intellectual recognition than currently given. The finding must be taken with some caution, in line with the earliermentioned limitation of the demanded professionalism having been derived from analysis of one job advert.

The role of intellect may also account for the ALDinHE descriptors yielding a very different picture to the UKPSF. The UKPSF applies to all staff with teaching responsibilities, of whom a majority will have research (therefore, 'intellect') as explicit within their job roles. In my poll, only $21 \%$ of Learning Development participants reported research as a paid work component, while an additional 50\% reported themselves as research-active outside of their salaried responsibilities. These results provide both positivity that the community 
recognises the importance of growing a research culture (Samuels, 2013; ALDinHE, 2018) and frustration that the view is only sporadically mirrored institutionally. If Learning Development and the UKPSF are to align more closely, a greater role for research in the demanded professionalism would be required. While again, gaining a fuller picture of demanded professionalism based on analysis of more job adverts could add weight to the point, the gap between the 'intellect' percentages on the ALDinHE community job description and the UKPSF is itself telling.

The similarity between the demanded and deduced professionalisms indicates clearly that the discourses from above and within have intersected (Evetts, 2014) to a perhaps unexpected extent. Although not uncovering the directionalities present within that process, the results seem to highlight a reconciliation between autonomy and accountability of the type Wilkins (2011) observed in teachers. It is noteworthy, however, that the ALDinHE community role descriptors illuminate only our open-to-the-public presentation of the role, not the reality of its delivery (Hoyle and Wallace, 2007). Located as that is behind the classroom or office door, enacted professionalism (Evans, 2008) is occluded from ready quantification. It is perhaps better accessed by investigating the views of Learning Developers, to which I now turn.

\section{For what do Learning Developers want professional recognition?}

The first three of my poll questions substantiated the finding (Murray and Glass, 2011) that the wide disparity in job titles associated with 'Learning Development' has sustained. 73\% of my respondents had 'development' in titles; for comparison, 'learning' was in 38\%, 'academic' in 31\% and 'skills' and 'support' each in 9\%. The result is seemingly in keeping with how ALDinHE members would want to enact their professionalism: removed from the semantic association with deficits of words like 'skills' and 'support' (Lea and Street, 1998; Wingate, 2006).

I also attempted to establish the most common words which finished job titles, themselves an indicator of professional status and salary grade (Murray and Glass, 2011). Despite my giving considerable forethought to the multiple-choice options (Tutor, Advisor, Lecturer, Officer, Assistant, Librarian and Specialist), the most selected response, at 36\%, was 'Other'. The result highlights starkly that our professional titles remain disparate. 
Regrettably, software limitations and my non-anticipation of the result meant the lack of a supplementary gap-fill question to unpack what 'Other' stood for. Regarding institutional location, and in parallel with Murray and Glass' (2011) finding, 62\% of respondents stated that their university offered primarily centrally-based Learning Development, most commonly in libraries, compared to $16 \%$ operating mainly departmental provision, and $23 \%$ with both models equally.

Respondents were also asked which activity occupied the largest proportion of their time. The highest response at $43 \%$ was one-to-one appointments, with $36 \%$ selecting embedded teaching and $21 \%$ nominating institution-wide activities. This result is interesting when compared to Murray and Glass' (2011) findings. Although they do not provide comparable statistics, they allude (p.29) to embedded and institutional work being, at the time, far more peripheral than one-to-one appointments and workshops. My own results suggest that while one-to-one work retains the biggest share of time spent, Learning Development is slowly becoming more embedded into course provision and institutional agendas, as per Samuels' (2013) recommendation.

Finally, to probe directly how Learning Developers might like to be professionally recognised, respondents were asked: "with which professional identity would you most associate yourself?" The results are shown in Figure 3.

\section{Figure 3. With which of these professional identities would you most associate yourself?}

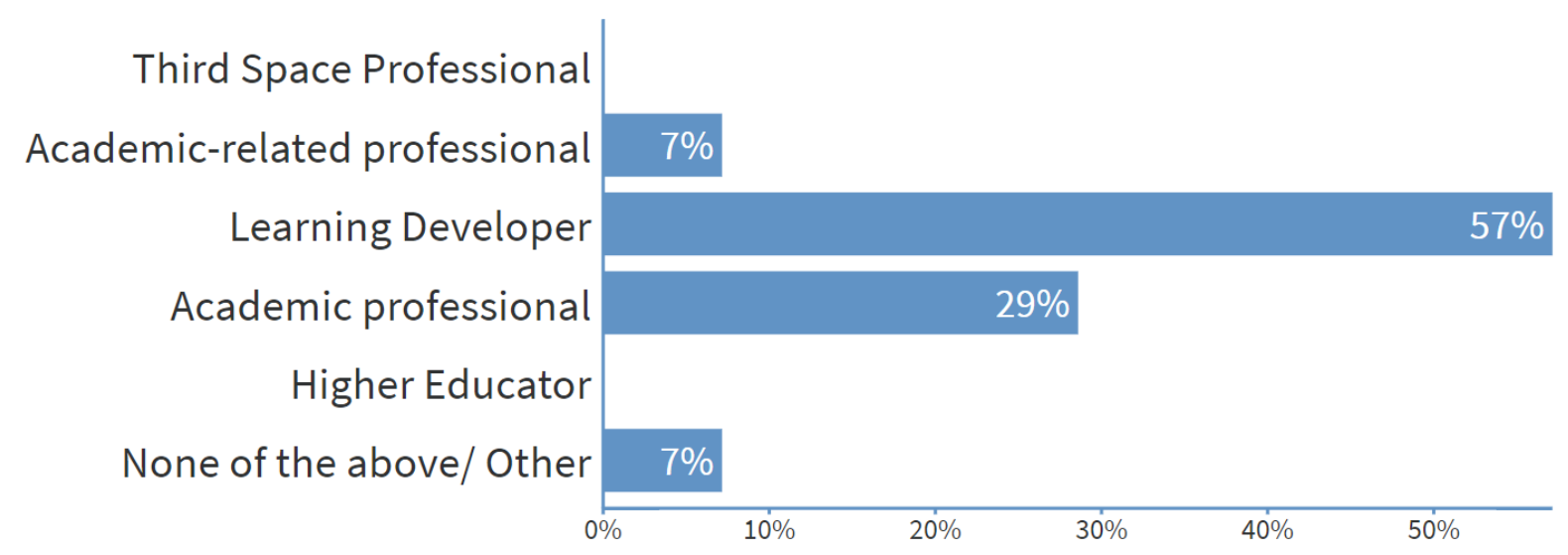


The selections are telling, in that 57\% selected 'Learning Developer' and 29\% 'Academic Professional', with no respondents primarily associating with 'Third Space Professional' or 'Higher Educator'. It is therefore evident that the distinct identity of 'Learning Developer' (not only the broader 'Learning Development') retains high importance among practitioners. I must acknowledge some slight limitations to this question. Firstly, some practitioners may associate with several of the identity options. Secondly, that the question included the word 'would' which meant it could be read ambiguously as either requesting the person's current reality or their hypothetical wish. The polling activity allowed these concerns to emerge in real-time and would lead me to reconsider the phrasing if repeating the research. Despite these points, as was my intention, the inclusion of the word 'you' did place the onus more on an internal interpretation than one externally imposed. Therefore, the results support a reasonable conclusion that Learning Development has not been subsumed within a bigger whole but remains important as something in and of itself. However, the subsequent discussion underlined the complexity in understanding what that 'something' is. The notion that Learning Development should strive for disciplinary recognition either alone (Samuels, 2013) or as a part of 'academic literacies' (respondent comment) proved problematic. The basis given, crucially, was, as one respondent commented, the lack of a subject base through which degree status can be conferred, itself seen as a precursor to academic disciplinary identity.

The discussion progressed to question whether Learning Development is close to having a subject base. The base, concerned with pedagogy in higher education, was discussed as being increasingly visible on programmes such as Degree Apprenticeships and PostGraduate Certificates in Education. The teaching of such programmes belongs within the traditional remit of 'Educational Development' although their presence in the LD-MAPS document (ALDinHE, 2015) suggests links with Learning Development also. Gibbs (2009) and Rust (2009) have claimed that the two groups' agendas are converging. If accepting that position in combination with Samuels' (2013) call for institutional alignment, then there is merit in Learning Development involvement on such programmes. As well as the profile it gives Learning Developers, our involvement creates opportunities for programmes to capture student-centred nuances to which we often enjoy the greatest access.

Above all, the group discussion illuminated the feeling that Learning Development is most visible as a set of core values and behaviours, which centred for one respondent on being 
'a non-judgemental space'. In the group, those considerations outweighed the need for 'Learning Developers' to strive for a common professional identity. I found the point of interest here to be that although in the poll, no participants selected 'Third Space' as a preferred professional identity, the group discussion emphasised the need to traverse boundaries (Whitchurch, 2008) in the pursuit of cross-curricular Learning Development. This appears paradoxical until it is understood that respondents regarded the values, more than the people involved, as needing to cross boundaries. Substantiating this finding fully would require the viewpoints of a larger sample of ALDinHE members, which would represent beneficial future research.

\section{Conclusions}

This study firstly sought to discover how external and internal perspectives on the professional identity of Learning Development compared. Evans' $(2008,2011)$ model of reified states of professionalism was used to show a professionalism 'demanded' of learning developers which is associated with agendas of widening participation, retention, skills and deficit-fixing. Learning Developers themselves, as expressed in ALDinHE's (2018) values, have a different belief set concerned with demystification of academic conventions as an emancipatory bridge between students' worlds inside and outside university.

Given all of that, it seems unsurprising that Learning Development has been positioned within a contested operational space (Hilsdon, 2017). However, as demanded professionalism undergoes filtration through individual and collective values, a point of convergence has been identified around delivering a morally-founded 'service' to students. This, I have argued, largely allows reconciliation between stakeholders' views, and creates space for Learning Developers to influence the future direction of our professional roles. A stronger and more coherent research voice for Learning Development may be vital in allowing that influence to be heard. When comparing the ALDinHE community's descriptors of job-role activity to those in the UKPSF, there was a noticeably reduced relative level of reference to 'intellect' in the internal descriptors. This was noted as a probable outcome of the small role played by research in LD-based roles compared to fully academic roles, a result corroborated in the poll by only $21 \%$ of those Learning Developers 
present declaring research as a paid responsibility. Encouragingly, however the ALDinHE (2018) community values include an explicit role for research, illustrating it as a priority that we wish to champion.

Conclusions to the second question of 'professionally recognised for what?' are, unsurprisingly, somewhat inconclusive. Due to the fragmented fashion in which Learning Development has grown, and the eclectic group of staff skillsets associated with it (Webster, 2015), such a final note may have been likely from the outset. However, there have been valuable gains from the exercise. The strongest consensus to emerge is that ALDinHE members wish to be professionally known for embodying Learning Development values, a view which mirrors the set-up of the CeP and CeLP practitioner recognition schemes (ALDinHE, 2018b).

The need to be visible and understood, and in so doing, to allow those values to permeate into the wider academic community, has also proven key. That led some within the group discussion to suggest that if Learning Development became universal among academics, then Learning Developers would become less necessary. Such a reality remains controversial and probably distant. For now, the key to enhancing visibility at the institutional level may be to work closely with influential staff outside of Learning Development, to ask and to challenge: 'what works here?' (Verity and Trowler, 2011). Towards that, involvement in degree apprenticeships/PGCert programmes in higher education was discussed as one possible route.

The niche carved out by and for Learning Development staff generally allows reconciliation between those professionalisms demanded of and enacted by us. Some doubt has been cast on whether, in the future, that parity can be maintained with all things remaining equal, or whether a more cohesive sense of our precise professional identity would be beneficial. Therefore, growing the collective voice of ALDinHE in relation to the issues raised remains critical, towards which I hope this paper provides a starting point. 


\section{Acknowledgements}

The author wishes to acknowledge Laura Barclay and Gordon Scruton, two peers who took the time to read drafts of the article in great depth and gave me valuable feedback which didn't shy away from constructive criticism, as well as convincing me that carrying on with writing the piece was worthwhile.

\section{References}

Apple, M. (2000) 'Can critical pedagogies interrupt rightist policies?', Educational Theory, 50(2), pp.229-254. https://doi.org/10.1111/j.1741-5446.2000.00229.x

Association for Learning Development in Higher Education (ALDinHE) (2015) LD-MAPS: learning development mapped against professional standards (UKPSF). Available at: https://aldinheprofdev.files.wordpress.com/2010/10/ld-maps-aug-2015.pdf (Accessed: 3 September 2018).

Association for Learning Development in Higher Education (ALDinHE) (2018) About the Association for Learning Development in Higher Education. Available at http://www.aldinhe.ac.uk/about/

Association for Learning Development in Higher Education (ALDinHE) (2018b) ALDinHE Recognition Scheme. Available at http://www.aldinhe.ac.uk/development/

Ball, S. (2000) 'Performativities and fabrications in the education economy: towards the performative society', Australian Educational Researcher, 27(2), pp. 1-23. https://doi.org/10.1007/BF03219719

Barnett, R. (2003) Beyond reason: living with ideology in the university. Buckingham: Society for Research into Higher Education. 
Beck, J. (2008) 'Governmental professionalism: re-professionalising or deprofessionalising teachers in England?', British Journal of Educational Studies, 56(2), pp. 119-143. https://doi.org/10.1111/j.1467-8527.2008.00401.x

Briggs, S. (2018) 'Development of the ALDinHE recognition scheme: certifying the 'learning developer' title', Journal of Learning Development in Higher Education, Issue 13, April, pp. 1-11. Available at: http://journal.aldinhe.ac.uk/index.php/jldhe/article/view/461/pdf (Accessed: 3 September 2018).

Briggs, S., Carter, A., Koulle, K. and Rafferty, V. (2018) 'An introduction to the ALDinHE Certified Practitioner (CeP) recognition scheme', ALDinHE 2018: The Learning Development Conference. University of Leicester, England 26-28 March.

Buckley, C. and Briggs, S. (2017) 'Community keynote: defining the future of learning development', ALDinHE 2017: The Learning Development Conference. University of Hull, England 10-12 April.

Clarke, M., Hyde, A. and Drennan, J (2013) 'Professional identity in higher education', in Kehm, B.M. and Teichler, U. (eds.) The academic profession in Europe: new tasks and new challenges. London: Springer, pp. 7-21.

Collini, S. (2017) Speaking of universities. London: Verso.

Day, C., Kington, A., Stobart, G. and Sammons, P. (2006) 'The personal and professional selves of teachers: stable and unstable identities', British Educational Research Journal, 32(4), pp. 601-616. https://doi.org/10.1080/01411920600775316

Denscombe, M. (2010) The good research guide. 4th edn. Maidenhead: Open University Press.

Evans, L. (2008) 'Professionalism, professionality and the development of education professionals', British Journal of Educational Studies, 56(1), pp. 20-38. https://doi.org/10.1111/j.1467-8527.2007.00392.x 
Evans, L. (2011) 'The 'shape' of teacher professionalism in England: professional standards, performance management, professional development and the changes proposed in the 2010 White Paper', British Educational Research Journal, 37(5), pp. 851-870. https://doi.org/10.1080/01411926.2011.607231

Evetts, J. (2014) 'The concept of professionalism: professional work, professional practice and learning', in Billett, S., Harteis, C. and Gruber, H. (eds.) International handbook of research in professional and practice-based learning. Springer, Dordrecht, pp. 29-56. https://doi.org/10.1007/978-94-017-8902-8

Gibbs, G. (1977) Can students be taught how to study? Higher Education Bulletin, 5, pp. 197-218.

Gibbs, G. (2009) 'Developing students as learners - varied phenomena, varied contexts and a developmental trajectory for the whole endeavour', Journal of Learning Development in Higher Education, Issue 1, February, pp. 1-12. Available at: http://journal.aldinhe.ac.uk/index.php/jldhe/article/view/30/14 (Accessed: 4 September 2018).

Freidson, E. (1999) 'Theory of professionalism: method and substance', International Review of Sociology, 9(1), pp. 117-129. https://doi.org/10.1080/03906701.1999.9971301

Harris, S. (2005) 'Rethinking academic identities in neo-liberal times', Teaching in Higher Education, 10(4), pp. 421-433. https://doi.org/10.1080/13562510500238986

Hatcher, R. (1994) Market relationships and the management of teachers, British Journal of the Sociology of Education, 15(1), pp. 41-61. https://doi.org/10.1080/0142569940150103

Higher Education Academy (HEA) (2011) The UK Professional Standards Framework for teaching and supporting learning in higher education. Available at: 
https://www.heacademy.ac.uk/system/files/downloads/uk professional standards $\mathrm{f}$ ramework.pdf (Accessed: 3 September 2018).

Hill, P. and Tinker, A. (2013) 'Integrating learning development into the student experience', Journal of Learning Development in Higher Education, 5, March, pp. 118. Available at: http://journal.aldinhe.ac.uk/index.php/ildhe/article/view/172 (Accessed: 3 September 2018).

Hilsdon, J. (2011) 'What is learning development?', in Hartley, P., Hilsdon, J., Keenan, C., Sinfield, S. and Verity, M. (eds.) Learning development in higher education. Basingstoke: Palgrave MacMillan, pp. 13-27.

Hilsdon, J. (2017) 'Problematising learning development', ALDinHE 2017: The Learning Development Conference. University of Hull, England, 10-12 April.

Hilsdon, J. (2018) 'Learning development: pedagogy, principles and progress', ALDinHE 2018: The Learning Development Conference. University of Leicester, England, 2628 Mar. Available at: https://www.slideshare.net/jhilsdon/hilsdon-keynote-aldinhe2018 (Accessed: 3 September 2018).

Hoyle, E. and John, P. (1995) Professional knowledge and professional practice. London: Cassell.

Hoyle, E. and Wallace, M. (2007) 'Educational reform: an ironic perspective', Educational Management, Administration and Leadership, 35(1), pp. 9-25. https://doi.org/10.1177/1741143207071383

Ivanic, R. and Lea, M. (2006) 'New contexts, new challenges: the teaching of writing in UK Higher Education', in Ganobcsik-Williams, L. (ed.) Teaching academic writing in UK Higher Education. Basingstoke: Palgrave MacMillan, pp. 6-15.

Johnson, I. (2018) 'Learning development and professionalism: driving ourselves forward', ALDinHE 2018: The Learning Development Conference. University of Leicester, England, 26-28 Mar. 
Johnson, T. (1972) Professions and power. Oxon: Routledge.

Kogan, M. (2000) 'Higher Education communities and academic identity', Higher Education Quarterly, 54(3), pp. 207-216. https://doi.org/10.1111/1468-2273.00156

Kolsaker, A. (2014) 'Relocating professionalism in an English university', Journal of Higher Education Policy and Management, 36(2), pp. 129-142. https://doi.org/10.1080/1360080X.2013.861053

Larson, M. (1977) The rise of professionalism. Berkeley: University of California Press.

Lea, M. and Street, B. (1998) 'Student writing in higher education: an academic literacies approach', Studies in Higher Education, 23(2), pp. 157-72. https://doi.org/10.1080/03075079812331380364

Lewis, K. (2014) 'Constructions of professional identify in a dynamic higher education sector', Perspectives: Policy and Practice in Higher Education, 18(2), pp. 43-50. https://doi.org/10.1080/13603108.2014.914107

Lillis, T. (2001) Student writing: access, regulation, and desire. Oxon: Routledge.

MacFarlane, B. (2011) 'The morphing of academic practice: unbundling and the rise of the para-academic', Higher Education Quarterly, 65(1), pp. 59-73. https://doi.org/10.1111/j.1468-2273.2010.00467.x

Marton, F., Hounsell, D. and Entwistle, N. (1984) The experience of learning: implications for teaching and studying in Higher Education. Edinburgh: Scottish Academic Press.

McClelland, C. (1990) 'Escape from freedom? Reflections on German professionalization 1870-1933' in Burrage, M. and Torstendahl, R. (eds.) The formation of professions: knowledge, state and strategy. London: Sage, pp. 97-113. 
Millerson, G. (1964) The qualifying associations: a study in professionalization. London: Routledge.

Murray, L. and Glass, B. (2011) 'Learning development in higher education - community of practice or profession?, in Hartley, P., Hilsdon, J., Keenan, C., Sinfield, S. and Verity, M. (eds.) Learning development in Higher Education. Basingstoke: Palgrave MacMillan, pp. 28-39.

Neal, M. and Morgan, J. (2000) 'The professionalization of everyone? A comparative study of the development of professions in the United Kingdom and Germany', European Sociological Review, 16(1), pp. 9-26. https://doi.org/10.1093/esr/16.1.9

Nixon, J. (2008) Towards the virtuous university: the new bases of academic professionalism. Abingdon: Routledge.

Ozga, J. and Lawn, M. (1981) Teachers, professionalism and class: a study in organised teachers. Lewes: Falmer Press.

Perkin, H. (1969) Key profession: the history of the association of university teachers. New York: Augustus M Kelley.

Robson, J. (2006) Teacher professionalism in further and higher education. Oxon: Routledge.

Rust, C. (2009) 'Opinion piece: a call to unite in a common cause', Journal of Learning Development in Higher Education, 1, February, pp. 1-5. Available at: http://journal.aldinhe.ac.uk/index.php/jldhe/article/view/24 (Accessed: 3 September 2018).

Samuels, P. (2013) 'Promoting learning as an academic discipline', Journal of Learning Development in Higher Education, 5, March, pp. 1-22. Available at: http://journal.aldinhe.ac.uk/index.php/jldhe/article/view/146 (Accessed: 3 September 2018). 
Sexton, M. (2007) 'Evaluating teaching as a profession - implications of a research study for the work of the teaching council', Irish Educational Studies, 26(1), pp. 79-105. https://doi.org/10.1080/03323310601125310

Shattock, M. (2014) 'Can we still speak of there being an academic profession?', History of Education, 43(6), pp. 727-739. https://doi.org/10.1080/0046760X.2014.964008

Staff and Educational Development Association (SEDA). (n.d.) Supporting and leading educational change. Available at: https://www.seda.ac.uk/ (Accessed: 3 September 2018).

Stronach, I., Corbin, B., McNamara, O., Stark, S. and Warne, T. (2002) 'Towards an uncertain politics of professionalism: teacher and nurse identities in flux', Journal of Education Policy, 17(1), pp. 109-138. https://doi.org/10.1080/02680930110100081

Training and Development Agency for Schools (2007) Professional standards for teachers. London: TDA publications.

Veles, N. and Carter, M.A. (2016) 'Imagining a future: changing the landscape for third space professionals in Australian higher education institutions', Journal of Higher Education Policy and Management, 38(5), pp. 519-533. https://doi.org/10.1080/1360080X.2016.1196938

Verity, M. and Trowler, P. (2011) 'Looking back and into the future', in Hartley, P., Hilsdon, J., Keenan, C., Sinfield, S. and Verity, M. (eds.) Learning development in Higher Education. Basingstoke: Palgrave MacMillan, pp. 241-252.

Webster, H. (2015) "Trust me, I'm a professional" - what do learning developers profess? ALDinHE 2015: The Learning Development Conference. Southampton Solent University, England, 30 March - 1 April.

Whitchurch, C. (2008) 'Shifting identities and blurring boundaries: the emergence of third space professionals in UK higher education', Higher Education Quarterly, 62(4), pp. 377-396. https://doi.org/10.1111/j.1468-2273.2008.00387.x 
Whitty, G. (2006) 'Teacher professionalism in a new era', paper presented at the first annual lecture of the General Teaching Council for Northern Ireland. Belfast, March. Available at:

http://www.gtcni.org.uk/publications/uploads/document/annual\%20lecture\%20paper .pdf (Accessed: 3 September 2018).

Wilkins, C. (2011) 'Professionalism and the post-performative teacher: new teachers reflect on autonomy and accountability in the English school system', Professional Development in Education, 37(3), pp. 389-409. https://doi.org/10.1080/19415257.2010.514204

Williams, K. (2008) 'Troubling the concept of the 'academic profession' in $21^{\text {st }}$ century higher education', Higher Education, 56(5), pp. 533-544. https://doi.org/10.1007/s10734-007-9109-x

Wingate, U. (2006) 'Doing away with 'study skills”, Teaching in Higher Education, 11(4), pp. 457-469. https://doi.org/10.1080/13562510600874268

Wolfendale, S. and Corbett, J. (1996) Opening doors: learning support in higher education. London: Cassell.

\section{Author details}

Ian Johnson is a Learning Developer of three years' experience in the School of Education and Sociology at University of Portsmouth. Prior to that, lan's background included teaching EAP, ESOL and adult literacy. 


\section{Appendix 1}

Example of my coding process using the LD-MAPS (ALDinHE, 2015) document

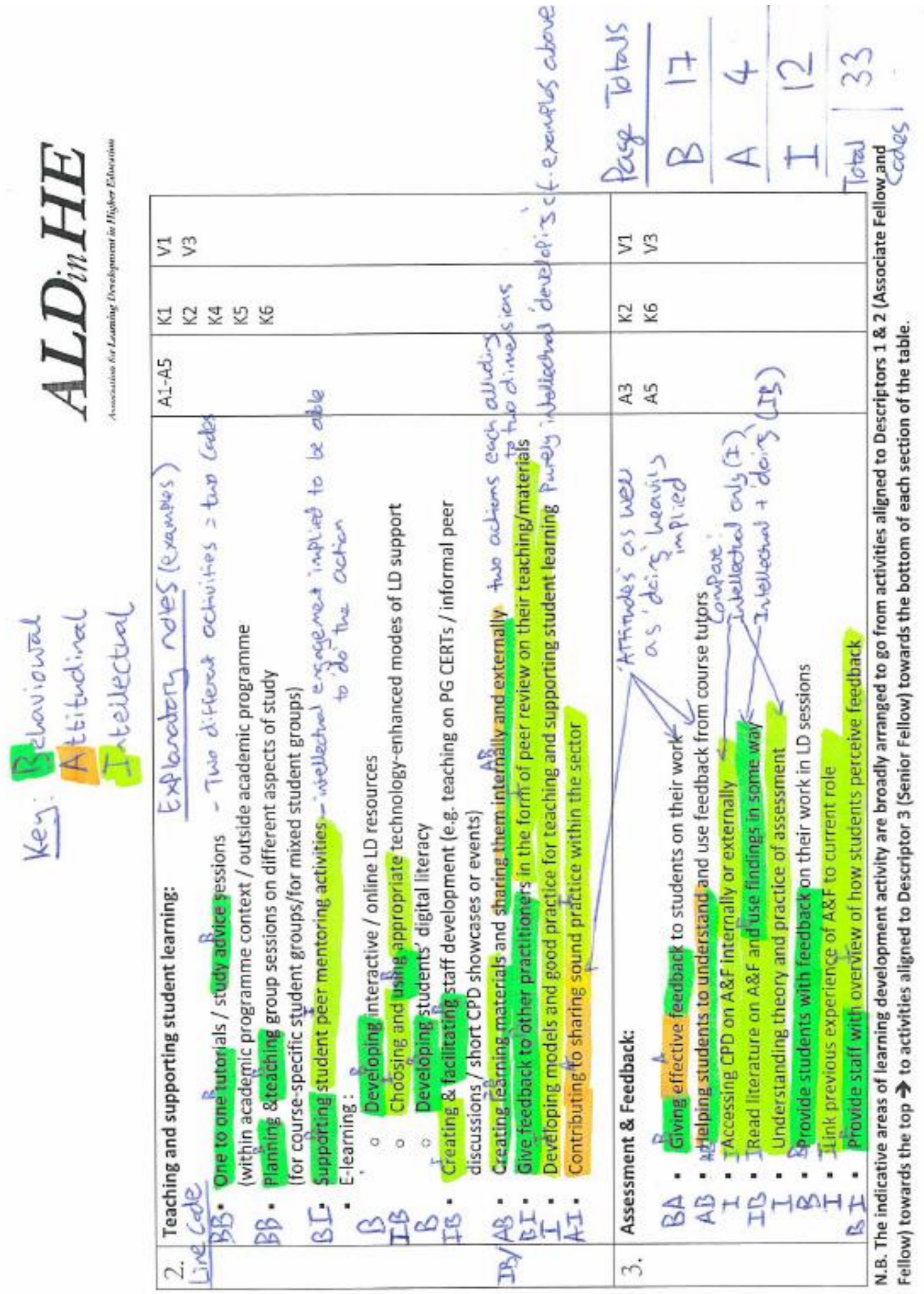




\section{Appendix 1 - DUPLICATE BLACK AND WHITE COPY}

Example of my coding process using the LD-MAPS (ALDinHE, 2015) document

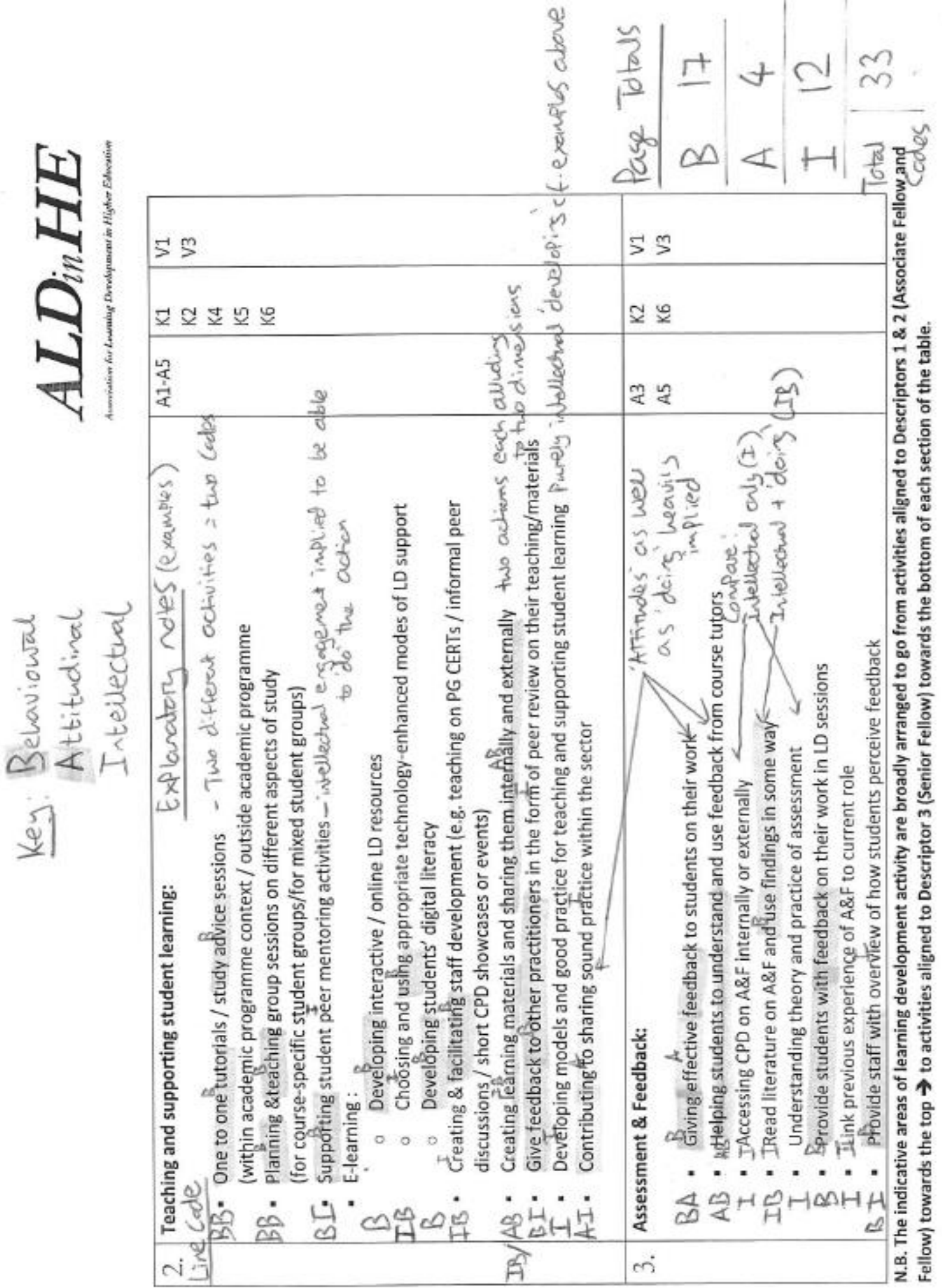


